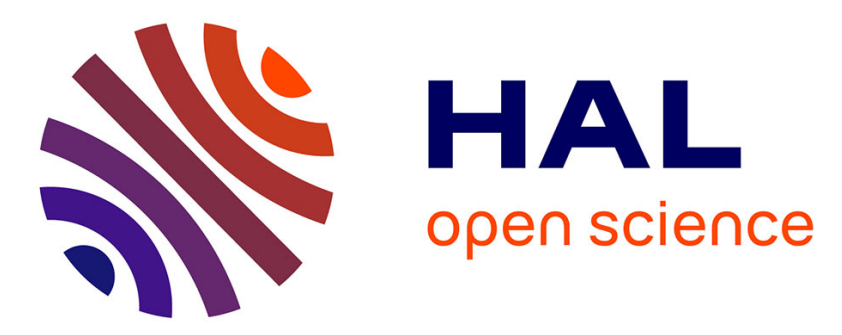

\title{
Archaeal diversity: Temporal variation in the arsenic-rich creek sediments of Carnoulès Mine, France
}

A. Volant, A. Desoeuvre, C. Casiot, Béatrice Lauga, S. Delpoux, G. Morin, J.C. Personné, M. Héry, F. Elbaz-Poulichet, P.N. Bertin, et al.

\section{- To cite this version:}

A. Volant, A. Desoeuvre, C. Casiot, Béatrice Lauga, S. Delpoux, et al.. Archaeal diversity: Temporal variation in the arsenic-rich creek sediments of Carnoulès Mine, France. Extremophiles, 2012, 16 (4), pp.645-657. 10.1007/s00792-012-0466-8 . hal-01631853

\section{HAL Id: hal-01631853 \\ https://hal.science/hal-01631853}

Submitted on 18 Jan 2022

HAL is a multi-disciplinary open access archive for the deposit and dissemination of scientific research documents, whether they are published or not. The documents may come from teaching and research institutions in France or abroad, or from public or private research centers.
L'archive ouverte pluridisciplinaire HAL, est destinée au dépôt et à la diffusion de documents scientifiques de niveau recherche, publiés ou non, émanant des établissements d'enseignement et de recherche français ou étrangers, des laboratoires publics ou privés. 


\title{
Archaeal diversity: temporal variation in the arsenic-rich creek sediments of Carnoulès Mine, France
}

\author{
A. Volant - A. Desoeuvre $\cdot$ C. Casiot $\cdot$ B. Lauga $\cdot$ S. Delpoux \\ G. Morin · J. C. Personné • M. Héry $\cdot$ F. Elbaz-Poulichet • \\ P. N. Bertin · O. Bruneel
}

\begin{abstract}
The Carnoulès mine is an extreme environment located in the South of France. It is an unusual ecosystem due to its acidic $\mathrm{pH}(2-3)$, high concentration of heavy metals, iron, and sulfate, but mainly due to its very high concentration of arsenic (up to $10 \mathrm{~g} \mathrm{~L}^{-1}$ in the tailing stock pore water, and $100-350 \mathrm{mg} \mathrm{L}^{-1}$ in Reigous Creek, which collects the acid mine drainage). Here, we present a survey of the archaeal community in the sediment and its temporal variation using a culture-independent approach by cloning of $16 \mathrm{~S}$ rRNA encoding genes. The taxonomic affiliation of Archaea showed
\end{abstract}

Communicated by F. Robb.

Electronic supplementary material The online version of this article (doi:10.1007/s00792-012-0466-8) contains supplementary material, which is available to authorized users.

A. Volant · A. Desoeuvre - C. Casiot - S. Delpoux ·

J. C. Personné · M. Héry · F. Elbaz-Poulichet · O. Bruneel ( $\square)$

Laboratoire HydroSciences Montpellier, HSM, UMR 5569

(IRD, CNRS, Universités Montpellier 1 et 2),

Université Montpellier 2, Place E. Bataillon, CC MSE,

34095 Montpellier, France

e-mail: bruneel@msem.univ-montp2.fr

\section{B. Lauga}

Equipe Environnement et Microbiologie, EEM, UMR 5254 (IPREM, CNRS), Université de Pau et des Pays de l'Adour, BP 1155, 64013 Pau, France

\section{G. Morin}

Institut de Minéralogie et de Physique des Milieux Condensés, IMPMC, UMR 7590 (CNRS, Université Pierre et marie curie/Paris 6), 4 place Jussieu, 75252 Paris, France

\section{P. N. Bertin}

Laboratoire de Génétique Moléculaire, Génomique, Microbiologie, GMGM, UMR 7156 (Université de Strasbourg, CNRS), Département Microorganismes, Génomes, Environnement, 28 Rue Goethe, 67083 Strasbourg, France a low degree of biodiversity with two different phyla: Euryarchaeota and Thaumarchaeota. The archaeal community varied in composition and richness throughout the sampling campaigns. Many sequences were phylogenetically related to the order Thermoplasmatales represented by aerobic or facultatively anaerobic, thermoacidophilic autotrophic or heterotrophic organisms like the organotrophic genus Thermogymnomonas. Some members of Thermoplasmatales can also derive energy from sulfur/iron oxidation or reduction. We also found microorganisms affiliated with methanogenic Archaea (Methanomassiliicoccus luminyensis), which are involved in the carbon cycle. Some sequences affiliated with ammonia oxidizers, involved in the first and rate-limiting step in nitrification, a key process in the nitrogen cycle were also observed, including Candidatus Nitrososphaera viennensis and Candidatus nitrosopumilus sp. These results suggest that Archaea may be important players in the Reigous sediments through their participation in the biochemical cycles of elements, including those of carbon and nitrogen.

Keywords Archaea - Diversity - Arsenic . Acid mine drainage $\cdot$ Lead and zinc mine

\section{Introduction}

Acid mine drainage (AMD) water is a worldwide environmental problem caused by active and abandoned mines (Johnson and Hallberg 2003). Mining and processing of sulfide-rich ores produce large amounts of pyrite-rich waste. In contact with meteoric water, oxidation of this material generates AMD. These effluents are generally characterized by a low $\mathrm{pH}$ and contain significant quantities of sulfates, metals and metalloids including arsenic. AMD generation is mainly mediated by acidophilic iron-oxidizing microorganisms 
(Edwards et al. 1999). Natural remediation of AMD can be observed at the Carnoulès site (France) or at Rio Tinto (Spain) (Casiot et al. 2003; Sánchez España et al. 2005). This natural remediation of metal pollutants is generally due to the occurrence of abiotic reactions and/or microbial activities that make these toxic compounds insoluble and lead to their accumulation in sediments (Hallberg 2010). These precipitations mainly involve the oxidation and precipitation of iron and the adsorption of other metals and metalloids by the resulting ferric minerals. Sulfate-reducing bacteria also have the ability to reduce sulfate to sulfide, which then reacts with certain dissolved metals to form insoluble precipitates (Hallberg 2010). In addition, several bacteria contribute to the immobilization of arsenic, thanks to their ability to oxidize this metalloid, arsenate $\mathrm{As}(\mathrm{V})$ being less soluble than arsenite As(III) (Bowell 1994).

The microbiology of AMD streams has been the subject of numerous studies. While a large amount of information is available on acidophilic bacteria indigenous to AMD, little is known about Archaea (Hallberg 2010). Several studies evidenced the presence of archaeal communities in acidic waters (Edwards et al. 2000; Dopson et al. 2004). The Archaea reported in AMD systems include groups of sulfur and/or iron-oxidizers, such as Sulfolobus, Acidianus, Metallosphaera, Sulfurisphaera, and Ferroplasma (Edwards et al. 2000; Golyshina et al. 2000; Baker and Banfield 2003). It has consequently been suggested that Archaea could also play a major role in the generation and remediation of AMD via oxidation of iron (Baker and Banfield 2003). Archaea may also play a role in the biogeochemical cycling of arsenic, for example, through the presence of Archaea that respire As(V) like Pyrobaculum aerophilum and Pyrobaculum arsenaticum (Huber et al. 2000; Oremland and Stolz 2003).

In a previous study, Bruneel et al. (2008) investigated the archaeal community in water samples from Carnoulès, an AMD very rich in metallic elements and especially arsenic compared to many others AMD. This study reported the presence of Ferroplasma acidiphilum and sequences affiliated to uncultured Thermoplasmatales archaeon. However, the archaeal population that inhabits the arsenic-rich Reigous sediments has never been characterized. Thus, to improve our understanding of AMD functioning, we characterized the archaeal communities present in sediment samples from the arsenic-rich AMD of the Carnoulès mine (France) and their temporal variations using a $16 \mathrm{~S}$ rRNA encoding gene library.

\section{Materials and methods}

Description of the study site

The $\mathrm{Pb}-\mathrm{Zn}$ Carnoulès mine, located in southern France, was closed in 1962. The mining extraction left about 1.2 Mt of solid sulfidic wastes containing $0.7 \mathrm{wt} \%$ lead, $10 \mathrm{wt} \%$ iron and $0.2 \mathrm{wt} \%$ arsenic, which are stored behind a $6 \mathrm{~m}$ high dam on the uppermost course of Reigous Creek. The seepage water, which percolates through the wastes, emerges at the base of the tailings dam, and is the initial source of Reigous Creek. The water is acidic $(2<\mathrm{pH}<3)$ and rich in dissolved sulfate, iron and arsenic (2000-7700, 500-1000 and 50-350 mg L ${ }^{-1}$, respectively) the later being predominantly in reduced forms: Fe(II) and As(III) (Casiot et al. 2003). The arsenic concentration decreases within the first $30 \mathrm{~m}$ of the creek mainly due to bacterial iron oxidation which leads to the coprecipitation of $20-60 \%$ of dissolved arsenic (Casiot et al. 2003). Although the arsenic level remains high, its concentration subsequently decreases by around $95 \%$ between the source of Reigous Creek and its confluence with the Amous River, $1.5 \mathrm{~km}$ downstream. The precipitates, which form around stromatolitic-like bacterial structures, are mainly composed of $\mathrm{Fe}(\mathrm{III})-\mathrm{As}$ (III) in winter in the first $10 \mathrm{~m}$ and of amorphous $\mathrm{Fe}(\mathrm{III})-\mathrm{As}(\mathrm{V})$ during the rest of the year (Casiot et al. 2003; Morin et al. 2003). Many studies (including culture-dependent and independent) have been conducted on the bacterial communities inhabiting the Carnoulès mine. Two of them focused specifically on sediment. The active bacterial species were identified in the sediments in the April 2006 library using high sensitivity nanoLC-chip-MS/MS methods combined with a $16 \mathrm{~S}$ rRNA based phylogenetic approach (Bruneel et al. 2011). This study showed that Gallionella, Thiomonas, Acidithiobacillus ferrooxidans, and Acidiphilium actively expressed proteins in situ. Meta- and proteo-genomics approaches were also used on sediments in the May 2007 library and allowed reconstruction of seven bacterial strains (Bertin et al. 2011). These studies and previous results (Casiot et al. 2003; Morin et al. 2003) suggest that the large amounts of As(V)$\mathrm{Fe}(\mathrm{III})$ hydroxysulfate sediments forming at Carnoulès may result from the combined activities of iron-oxidizing microorganisms (such as At. ferrooxidans, Alicyclobacillus ferrooxidans, Ferrimicrobium, or Gallionella) and arsenicoxidizing microorganisms (such as Thiomonas sp.).

Sampling procedure and measurement of physicochemical properties

Four sampling campaigns were carried out in April 2006, October 2008, January 2009 and November 2009. Samples were collected at the station called COWG (Carnoulès Oxidizing Wetland, point $\mathrm{G}$ ) located $30 \mathrm{~m}$ downstream of the spring (Bruneel et al. 2003). $5 \mathrm{~cm}$ deep pale yellow loosely packed sediments were collected at the bottom of the creek using a sterile spatula and pooled [global positioning system (GPS) coordinates: 44107001.8000N/ 4100006.9000E]. This sampling was done in three replicates. Solid phases were harvested by centrifugation and 
dried under vacuum before mineralogical and spectroscopic analyses. The main physicochemical parameters ( $\mathrm{pH}, \mathrm{T}{ }^{\circ} \mathrm{C}$, and dissolved oxygen concentration) of the running water at the sampling point were measured in the field. $\mathrm{pH}$ and water temperature were measured with an Ultrameter Model 6P (Myron L 125 Company, Camlab, Cambridge). Water samples $(500 \mathrm{ml})$ were immediately filtered through $0.22 \mu \mathrm{m}$ Millipore membranes fitted on Sartorius polycarbonate filter holders. For total iron and arsenic determination, the filtered water was acidified to $\mathrm{pH}$ 1 with $\mathrm{HNO}_{3}(14.5 \mathrm{M})$ and stored at $4{ }^{\circ} \mathrm{C}$ in polyethylene bottles until analysis. For arsenic and iron speciation, a $20 \mu \mathrm{l}$ aliquot of filtered water sample was added to either a mixture of acetic acid and EDTA (Samanta and Clifford 2005) for arsenic speciation or to a mixture of $0.5 \mathrm{ml}$ acetate buffer ( $\mathrm{pH} 4.5)$ and $1 \mathrm{ml}$ of 1,10-phenanthrolinium chloride solution (Rodier et al. 1996) for Fe(II) determination. The vials were completed to $10 \mathrm{ml}$ with deionized water. The samples for iron and arsenic speciation and sulfate determination were stored in the dark and analyzed within $24 \mathrm{~h}$. Chemical analysis were carried out as previously described (Bruneel et al. 2011).

\section{Solid sample characterization}

The mineralogical composition of the solid samples collected at COWG was qualitatively determined using powder $\mathrm{X}$-ray diffraction analysis (XRD). Data were collected with Co K-alpha radiation on an X'Pert PRO P analytical diffractometer equipped with an $\mathrm{X}^{\prime}$ Celerator detector, in continuous mode and a counting time of $4 \mathrm{~h}$ per sample. X-ray absorption spectroscopy data were collected on the solid phases sampled at COWG in October 2008, January 2009, and November 2009. X-ray absorption near edge structure (XANES) and extended X-ray absorption fine structure (EXAFS) spectra were recorded at a temperature 10-15 K in fluorescence mode on the FAME BM30B bending magnet beamline at ESRF (Grenoble, France). Data for the April 2006 COWG sample were previously collected at the 11-2 wiggler beamline at SSRL (Stanford, CA) and analyzed in Bruneel et al. (2011). Experimental details and data reduction procedures are reported in previous studies (Morin et al. 2003; Ona-Nguema et al. 2005; Hohmann et al. 2011). XANES and EXAFS data were interpreted by linear combination fitting using a set of model compound spectra. This set includes As(V)- and As(III)-Fe(III) oxyhydroxides and oxyhydroxysulfates synthesized via biotic and abiotic pathways (Morin et al. 2003; Maillot 2011).

\section{DNA isolation}

Triplicate genomic DNA was extracted from sediments using the UltraClean Soil DNA Isolation Kit according to the manufacturer's recommendations (MoBio Laboratories Inc., Carlsbad, CA, USA). These triplicates were pooled before PCR amplification. All extracted genomic DNA samples were stored at $-20{ }^{\circ} \mathrm{C}$ until further analysis.

\section{PCR amplification}

Amplification of archaeal 16S rRNA genes was obtained by PCR using primers Arch21F ( $5^{\prime}$-TTCCGGTTGATCC YGCCGGA-3') and Arch958R (5'-YCCGGCGTTGAMTC CAATT-3') (Delong 1992). Two PCR protocols were used due to major amplification difficulties. The first PCR amplification mixture contained $2 \mu \mathrm{l}$ of DNA template, $2 \mu \mathrm{l}$ of both primers $(20 \mu \mathrm{M}), 25 \mu \mathrm{l}$ of PCR Master Mix Ampli Taq Gold 360 (Applied Biosystems, Foster City, CA, USA). Sterile distilled water was added to reach a final volume of $50 \mu \mathrm{l}$. The PCR conditions were as follows, an initial denaturation step of $95{ }^{\circ} \mathrm{C}$ for 7 min followed by 35 denaturation cycles at $95{ }^{\circ} \mathrm{C}$ for $1 \mathrm{~min}$, an annealing cycle at $55{ }^{\circ} \mathrm{C}$ for $45 \mathrm{~s}$ and an extension cycle at $72{ }^{\circ} \mathrm{C}$ for $1 \mathrm{~min}$. Final extension was at $72{ }^{\circ} \mathrm{C}$ for $10 \mathrm{~min}$. As amplification of the January 2009 sample failed with this protocol, another enzyme was used, the PCR Extender Polymerase Mix (5Prime, Hamburg, Deutschland) as well as for a part of the November 2009 sample, which was also very difficult to amplify. The second PCR amplification mixture contained $2 \mu \mathrm{l}$ of DNA template, $2 \mu \mathrm{l}$ of both primers $(20 \mu \mathrm{M}), 2.5 \mu \mathrm{l}$ of dNTPs $10 \mathrm{mM}, 5 \mu \mathrm{l}$ reaction Tunning buffer $\times 10$ and $0.5 \mu \mathrm{l}$ of PCR Extender Polymerase Mix (5Prime, Hamburg, Deutschland). Sterile distilled water was added to reach a final volume of $50 \mu \mathrm{l}$. The PCR conditions were as follows: initial denaturation step at $94{ }^{\circ} \mathrm{C}$ for $3 \mathrm{~min}$ followed by 35 denaturation cycles at $94{ }^{\circ} \mathrm{C}$ for $1 \mathrm{~min}$, an annealing cycle at $55^{\circ} \mathrm{C}$ for $1 \mathrm{~min}$, and an extension cycle at $72{ }^{\circ} \mathrm{C}$ for $1.5 \mathrm{~min}$. Final extension was at $72{ }^{\circ} \mathrm{C}$ for $10 \mathrm{~min}$. PCR products were purified with the GFX PCR DNA purification kit (AmershamPharmacia). The PCR Extender polymerase mix creates blunt ended products. For TA Cloning ${ }^{\circledR}, 3^{\prime}$ A-overhangs are needed on these PCR products, which are obtained with a different Taq polymerase. To $25 \mu \mathrm{l}$ of purified PCR product, $2.5 \mu \mathrm{l}$ of buffer $10 \times, 0.5 \mu \mathrm{l}$ of dATPs $10 \mathrm{mM}$, and $0.5 \mu \mathrm{l}$ of Taq DNA polymerase (Eurobiotaq ${ }^{\circledR}$, Eurobio, France) were added. The PCR amplification mixture was then incubated at $72{ }^{\circ} \mathrm{C}$ for $20 \mathrm{~min}$.

\section{Cloning and 16S rRNA gene sequencing}

The PCR products were cloned in E. coli TOP 10 strain using the pCR2.1 Topo TA cloning kit (Invitrogen, Inc., Carlsbad, CA, USA). Cloned 16S rRNA gene fragments were re-amplified using the primers TOP1 (5'-GTGTGCT GGAATTCGCCCTT-3') and TOP2 (5'-TATCTGCAGAA 
TTCGCCCTT- $3^{\prime}$ ) that anneal to the vector and flank the inserted PCR fragment. A total of 340 clones from the four libraries were sequenced. Partial sequences of the clones were determined by the dideoxy nucleotide chain-termination method using the BigDye 3.1 kit (Applied Biosystems) on an ABI PRISM 3730XL Genetic analyzer (Applied Biosystems). The MALLARD program (Ashelford et al. 2006) was used to detect and then remove chimera. Sequences were also examined manually for chimera, which were excluded from further analyses. Sequences were then aligned in Mothur (http://www.mothur.org) (Schloss et al. 2009) using the SILVA archaeal database as reference alignment. The same program was used to calculate a neighbor-joining (NJ) (Saitou and Nei 1987) distance matrix using the Jukes-Cantor (JC) correction. The matrix was then used to assign sequences to operational taxonomic units (OTUs) defined at 97 (species level) and $85 \%$ (class level) cutoff using the furthest-neighbor algorithm. Sequences were compared with the available databases NCBI and Greengenes (http://greengenes.lbl.gov) by BLAST online searches (Altschul et al. 1990) and Mothur to identify their taxonomic identities. Representative sequences for each OTU defined at $97 \%$ cutoff were identified using the tool implemented in Mothur and were submitted to the EMBL databases under accession numbers (HE653775-HE653816).

Phylogenetic analysis

Archaeal 16S rRNA gene homologs were collected from the database at NCBI using the BLAST program with default parameters; one representative of each OTU was selected, giving a dataset of 99 sequences for final analysis. Multiple sequence alignment of partial prokaryotic sequences was performed using Clustal W (Thompson et al. 2000). A maximum likelihood phylogenetic reconstruction was obtained using the PhyML program (Guindon and Gascuel 2003) with the GTR model, four evolutionary rates, a calculated proportion of invariant sites and calculated nucleotide frequencies (default parameters). Statistical likelihood at nodes was calculated via a likelihood-ratio test (Anisimova and Gascuel 2006).

Statistical analysis of diversity and comparison of archaeal libraries

The Mothur software package was also used to generate diversity indices and statistics (OTUs, total clones, singletons, Chao1, Shannon, evenness, coverage) for each clone library as sequence similarity with a $97 \%$ cutoff. The total number of clones obtained compared with the number of clones representing each unique phylotype was used to produce the rarefaction curves at the $85 \%$ level. Coverage values were calculated to determine how efficiently the libraries described the complexity of a theoretical community like an original archaeal community. The coverage (Good 1953) value is given as $C=1-\left(n_{1} / N\right)$ where $n_{1}$ is the number of clones that occurred only once in the library. To determine the significance of differences between archaeal libraries, a LIBSHUFF statistical analysis was performed in Mothur following Singleton et al.'s (2001) method. A LIBSHUFF comparison of libraries yielded the following formula using the Bonferroni correction: $0.05=1-(1-a) k(k-1)$, where $a$ is the critical $P$ value and $k$ is the number of libraries. The critical $P$ value is 0.0042 when four libraries are compared. If any comparison of two libraries has a $P$ value below or equal to 0.0042 , then there is $95 \%$ confidence to believe that the two libraries concerned differ significantly in community composition. Jaccard and Yue \& Clayton theta tree clustering analysis (Yue and Clayton 2005) were also performed in Mothur to identify community membership and structure relationships between the libraries.

\section{Results}

Physical and chemical characteristics of samples

The physicochemical characteristics of the waters are listed in Table 1. The physicochemistry of Reigous Creek water at these sampling periods was typical of that observed during a previous long-term monitoring study (Egal et al. 2010). The water samples were acid $(\mathrm{pH}=2.91-3.28)$ and very rich in sulfate $\left(1830-3400 \mathrm{mg} \mathrm{L}^{-1}\right)$, iron (510-1735 $\left.\mathrm{mg} \mathrm{L}^{-1}\right)$, and arsenic (70-194 $\mathrm{mg} \mathrm{L}^{-1}$ ), with predominance of the reduced forms $\mathrm{Fe}$ (II) and As(III). Dissolved oxygen concentrations ranged from 3.5 to $7.86 \mathrm{mg} \mathrm{L}^{-1}$. The January 2009 sample showed the lowest iron, arsenic, and sulfate concentrations.

The nature and structure of the sediment samples were investigated using mineralogical and spectroscopic methods. XANES analyses at the arsenic K-edge showed that, despite the presence of an As(III) component equal to $12-34 \pm 5 \%$ of total arsenic, the oxidized arsenic form $\operatorname{As}(\mathrm{V})$ predominated in all the sediments (Fig. S1). EXAFS data (Fig. S2) showed that As(V) was mainly present in the samples in an amorphous $\mathrm{Fe}(\mathrm{III})-\mathrm{As}(\mathrm{V})$ hydroxysulfate phase, as previously observed (Morin et al. 2003; Bruneel et al. 2011), As(III) being likely sorbed to poorly ordered schwertmannite. For January 2009, there was not enough time exposure to X-ray beam in EXAFS analysis to record this sample, however, based on the XANES data we can assume that this sample should be similar to the others. XRD analyses (Fig. S3) showed that these arsenic-bearing phases were mixed with sandy components (quartz, 
Table 1 Physico-chemical characteristics of the water $\left(\mathrm{mg} \mathrm{L}^{-*}\right)$ during sampling at COWG

\begin{tabular}{llllllrrr}
\hline Sampling period & $\mathrm{pH}( \pm \mathrm{SD})$ & $\mathrm{T}\left({ }^{\circ} \mathrm{C}\right)$ & $\mathrm{DO}( \pm \mathrm{SD})$ & $\mathrm{As}(\mathrm{III})( \pm \mathrm{SD})$ & $\mathrm{As}(\mathrm{V})( \pm \mathrm{SD})$ & $\mathrm{Fe}(\mathrm{total})( \pm \mathrm{SD})$ & $\mathrm{Fe}(\mathrm{II})( \pm \mathrm{SD})$ & $\mathrm{S} 042^{-}( \pm \mathrm{SD})$ \\
\hline April 2006 & $3.28( \pm 0.05)$ & 12.9 & $3.5( \pm 0.5)$ & $69( \pm 3)$ & $71( \pm 4)$ & $620( \pm 30)$ & $560( \pm 28)$ & $2700( \pm 300)$ \\
October 2008 & $3.13( \pm 0.05)$ & 14.3 & $5.7( \pm 0.1)$ & $133( \pm 7)$ & $20( \pm 1)$ & $1250( \pm 62)$ & $1220( \pm 61)$ & $3400( \pm 340)$ \\
January 2009 & $2.91( \pm 0.05)$ & 9.4 & $5.5( \pm 0.5)$ & $43( \pm 2)$ & $27( \pm 1)$ & $510( \pm 25)$ & $540( \pm 27)$ & $1830( \pm 183)$ \\
November 2009 & $3.26( \pm 0.05)$ & 13.1 & $7.9( \pm 0.1)$ & $161( \pm 8)$ & $33( \pm 2)$ & $1735( \pm 87)$ & $1440( \pm 72)$ & $3300( \pm 330)$ \\
\hline
\end{tabular}

$S D$ standard deviation

K-feldspar and micas) and that pyrite was only detected after October 2008.

Diversity analysis

A total of 340 clones obtained from the four independent 16S rRNA gene libraries were fully sequenced and phylogenetically analyzed. Thirteen sequences were identified as likely chimeras and excluded from further analyses. Sequencing and phylogenetic analysis of the 327 remaining cloned sequences led to the identification of 9 and 42 OTUs defined at two different levels of identity (85 and $97 \%$, respectively). Rarefaction curves calculated at the class level ( $85 \%$ identity, the rank usually used for representing the microbial community) were near saturation (Fig. I). Table 2 shows the Shannon, evenness, and Chaol indices and the coverage values calculated for each library at $97 \%$ identity. The coverage values of the four clone libraries (90, 88, 96 and 92, respectively, for April 2006, October 2008, January 2009, and November 2009) indicate that the clone libraries were sufficiently sampled. The estimations of the diversity indices show that the structure and membership composition of the archaeal community changed over the sampling period. The Shannon diversity $(\mathrm{H})$ and Chaol richness indices ranged from 1.37 to 2.57 and 6.5 to 30.5 , respectively. The diversity $(H=1.37)$ and richness $($ Chaol $=6.5)$ were significantly lower in January 2009 whereas November 2009 displayed the highest values $(\mathrm{H}=2.57$; Chaol $=30.5)$, which is consistent with the rarefaction curves.

Comparison of archaeal community

The overall community structure was analyzed for each sample using the Mothur software package. LIBSHUFF analysis was performed to compare the OTU compositions of each clone library revealing a high degree of variation between individuals and showing that with Bonferroni correction, each library differed significantly from all others (Table 3). The resulting dendrograms of Jaccard and Yue \& Clayton theta similarity coefficient analysis (Fig. 2) identified one major cluster and one outlier (January 2009). The similarity in community membership (Jaccard index,

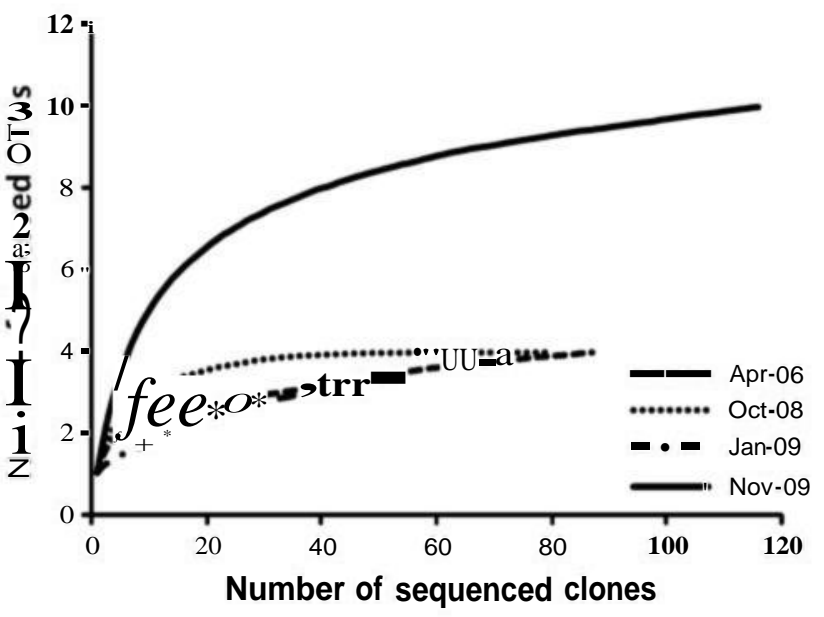

Fig. 1 Rarefaction curves of the archaeal 16S rRNA sequences from Carnoulès mine sediments at $85 \%$ identity. The total number of sequenced clones is plotted against the number of OTUs observed in the same library

Fig. 2a) showed that April 2006 and November 2009 were more related to each other in this respect, whereas April 2006 and October 2008 were more related to each other in terms of community structure (Yue \& Clayton index. Fig. 2b).

Phylogenetic analysis of archaeal community

Four 16S rRNA encoding gene libraries were constructed each containing a distinct archaeal community, which varied in composition and richness throughout the sampling campaigns.

In April 2006, the $16 \mathrm{~S}$ rRNA phylogenetic reconstruction (Fig. 3) showed that all the sequences corresponding to 17 OTUs (OTUs 1-17) were affiliated to the phylum Euryarchaeota, as previously observed in the water samples from Carnoulès (Bruneel et al. 2008). The most abundant OTU (OTU 1, 53 clones representing around $61 \%$ of the sample) was affiliated to the order Thermoplasmatales which contained $97 \%$ of the sequences grouped in 15 OTUs. Within this order, the majority of the OTUs were closely related to uncultured clones from an acidic environment such as acidic mine water and sediments (Fig. 3). 
Table 2 Diversity indices and statistics calculated for the four clone libraries from COWG station at different sampling periods

\begin{tabular}{lcccccc}
\hline Clone library & No. of sequences & No. of OTUsa & Singletons & Good's coverage $^{* 1}$ & Shannon diversity $^{{ }^{*}}$ Chaol richness \\
\hline April 2006 & 87 & 17 & 9 & 90 & 1.63 & 24.2 \\
October 2008 & 80 & 20 & 10 & 88 & 1.96 & 27.5 \\
January 2009 & 47 & 6 & 2 & 96 & 1.37 & 6.5 \\
November 2009 & 113 & 25 & 9 & 92 & 2.57 & 30.5 \\
\hline
\end{tabular}

" OTUs were defined at $97 \%$ cutoff

b Coverage: sum of probabilities of observed classes calculated as $(\mathrm{I}-(n / N))$, where $n$ is the number of singleton sequences and $N$ is the total number of sequences

c Takes into account the number and evenness of species

Table 3 Community comparison using LIBSHUFF

\begin{tabular}{|c|c|c|c|c|}
\hline & \multicolumn{4}{|l|}{ Y library } \\
\hline & Apr-06 & Oct-08 & Jan-09 & Nov-09 \\
\hline \multicolumn{5}{|l|}{ X library } \\
\hline Apr-06 & - & 0.0260 & $<0.0001 *$ & 0.1529 \\
\hline Oct-08 & $0.0001 *$ & - & $<0.0001 *$ & $0.0001 *$ \\
\hline Jan-09 & $<0.0001 *$ & $<0.0001 *$ & - & 0.2222 \\
\hline Nov-09 & $<0.0001^{*}$ & $<0.0001^{*}$ & $<0.0001 *$ & - \\
\hline
\end{tabular}

* Significant difference. Bonferroni correction $P$ value $=0.0042$

- Not compared

The BLAST affiliation (Table 4) showed that some of these OTUs displayed 89-94\% similarity with Thermogymnomonas acidicola, a moderately thermophilic, acidophilic, strictly aerobic heterotroph that uses yeast extract, as well as glucose and mannose (in the presence of yeast extract) as carbon and energy sources (Itoh et al. 2007). Additionally, OTU 15 related to the uncultured clone ORCMO 26 retrieved from a copper mine drainage (Rowe et al. 2007, Fig. 3) was found. This OTU was assigned to methanogenic lineage (Methanomicrobia, Fig. 3) with the closest relative Methanomassiliicoccus luminyensis, a methanogenic Archaea recently isolated from human faeces (Dridi et al. 2011). However, the Greengenes classification (Table 4) assigned this OTU to the order Thermoplasmatales. Lastly, an unknown group belonging to the Euryarchaeota and represented by OTU 8 was detected. This group formed an independent branch that was distantly related to the identified groups and showed low similarity with the uncultured archaeon clone hfm29 isolated from an iron-rich microbial mat (Kato et al. in press).

Twenty OTUs were retrieved from the October 2008 library, 18 of which belonged to the Euryarchaeota and two to the Thaumarchaeota (Fig. 3). Like in April 2006, most of the Euryarchaeota sequences were affiliated with the Thermoplasmatales (OTUs 1, 6, 9, 11, 12, 17, 19, 20, a

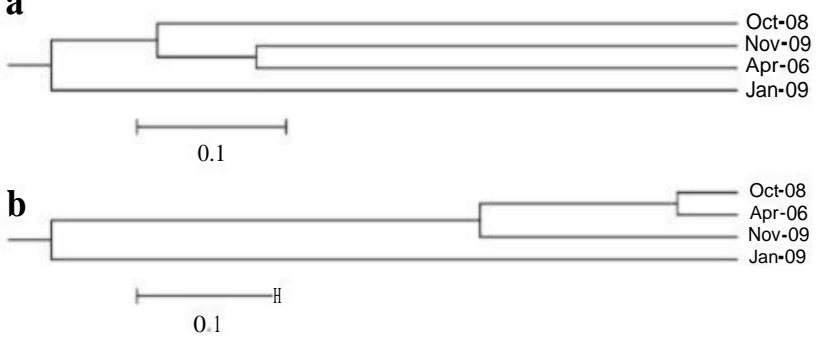

Fig. 2 Similarities in archaeal community membership (Jaccard a) and in community structure (Yue \& Clayton b) between samples. Values are based on 0.03 distances

22-27, and 31) which accounted for $86 \%$ of the total archaeal clones including the same most abundant OTU (OTUI; around $54 \%$, Fig. 3). The BLAST affiliation (Table 4) also revealed similarity of some OTUs with Thermogymnomonas acidicola. Three OTUs (18, 21, and 28) affiliated with uncultured clones isolated from acidic environments (clone SALE1B1 and clone anta6) and from a forested wetland impacted by reject coal (clone ARCP212) (Brofft et al. 2002; Garcia-Moyano et al. 2007, Fig. 3), respectively, were assigned to Methanomicrobia. The remaining OTUs (OTUs 29 and 30) were affiliated with environmental sequences originating from acidic soil and acidic hot springs, which likely represent uncultured lineages of Thaumarchaeota.

A significant change in the archaeal community appeared in the January 2009 library, when diversity decreased and no cultured species were identified. Indeed, almost all the sequences $(96 \%$ ) clustered in five OTUs (OTUs 8, 32, 33, 34, and 35, Fig. 3) were related to the uncultured archaeon clone hfmA029 previously found in April 2006. This group formed an independent branch that was far away from the remaining groups. This clone displayed around $97 \%$ similarity with Methanothermobacter thermautotrophicus, an autotrophic thermophilic methanogen recovered from an anaerobic sewage sludge digester (Zeikus and Wolee 1972). Remaining sequences grouped 


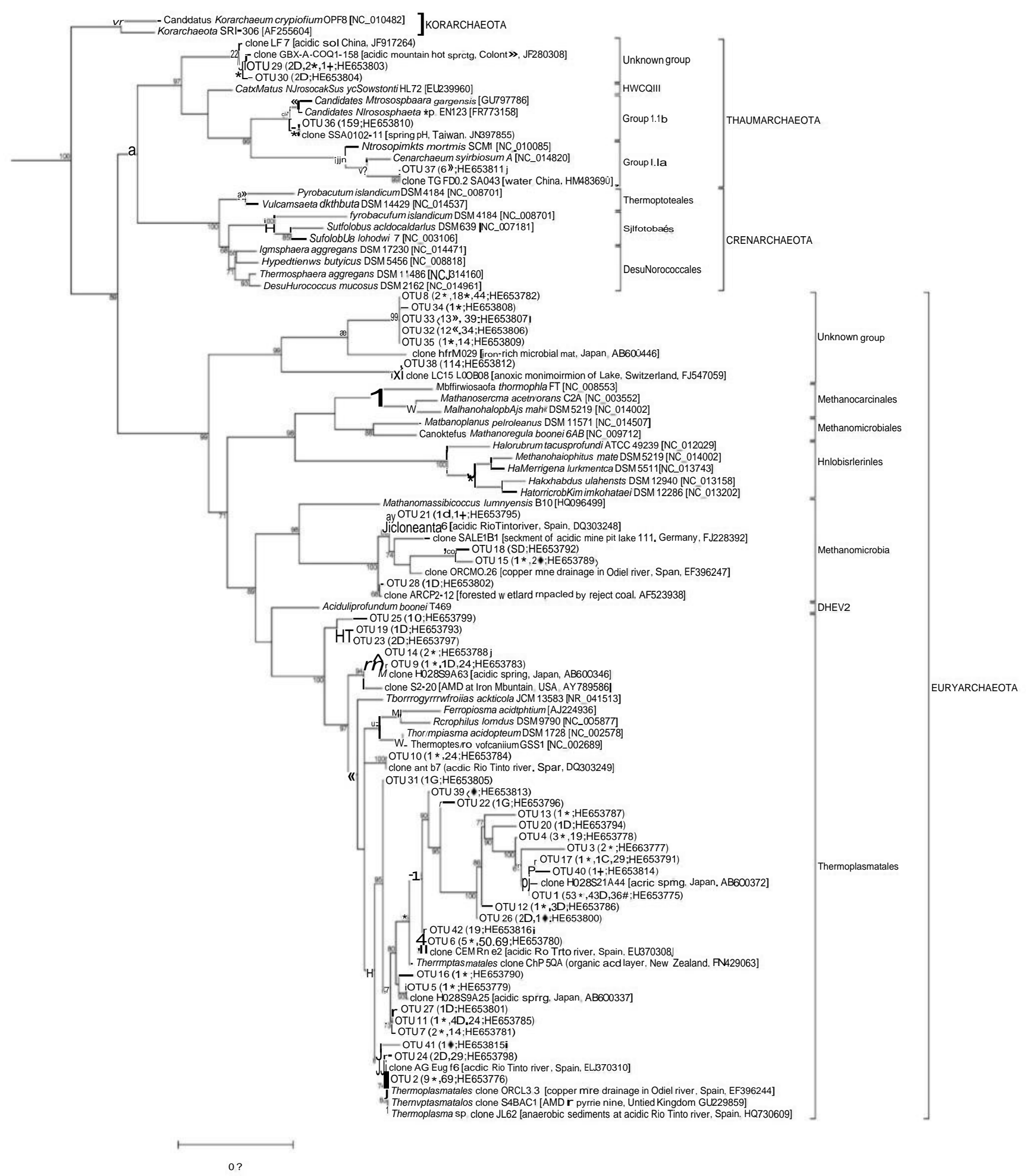

Fig. 3 Maximum likelihood tree of 16S rRNA gene homologs from the archacal clones (in hold) along with a selection of representatives of archaeal diversity. Numbers at nodes indicate a LTR (approximate likelihood ratio test) branch support as computed by PhyML. The scale bar gives the average number of substitutions per site. The number in parenthesis indicates the number of clones for the sampling period which is represented by a symbol (star April 2006, square October 2008, circle January 2009 and diamond November 2009) 
Table 4 Identification number of the OTUs retrieved from the Reigous Creek sediment of Carnoulès mine, taxonomic affiliation and representative sequence for each OTU

\begin{tabular}{|c|c|c|c|c|c|c|}
\hline \multirow{2}{*}{$\begin{array}{l}\text { OTU } \\
\text { ID }\end{array}$} & \multirow{2}{*}{$\begin{array}{l}\text { Number of } \\
\text { sequences }\end{array}$} & \multirow{2}{*}{$\begin{array}{l}\text { Representative } \\
\text { sequence }\end{array}$} & \multicolumn{3}{|c|}{ Taxonomic affiliation } & \multirow[t]{2}{*}{ Closest relative ( $\%$ of identity) } \\
\hline & & & Phylum & Class & Order & \\
\hline 1 & 132 & ArCMSdO8D35 & Euryarchaeota & Thermoplasmata & Thermoplasmatales & $\begin{array}{l}\text { Aciduliprofundum sp. EPR07-39 } \\
\quad(85 \%)\end{array}$ \\
\hline 2 & 15 & ArCMSdA6A12 & Euryarchaeota & Thermoplasmata & Thermoplasmatales & $\begin{array}{l}\text { Thermogymnomonas acidicola JCM } \\
13583(89 \%)\end{array}$ \\
\hline 3 & 2 & ArCMSdA6A86 & Euryarchaeota & Thermoplasmata & Thermoplasmatales & $\begin{array}{l}\text { Aciduliprofundum sp. EPR07-39 } \\
\quad(85 \%)\end{array}$ \\
\hline 4 & 4 & ArCMSdA6A46 & Euryarchaeota & Thermoplasmata & Thermoplasmatales & $\begin{array}{l}\text { Thermogymnomonas acidicola JCM } \\
13583(90 \%)\end{array}$ \\
\hline 5 & 1 & ArCMSdA6A17 & Euryarchaeota & Thermoplasmata & Thermoplasmatales & $\begin{array}{l}\text { Thermogymnomonas acidicola JCM } \\
13583(91 \%)\end{array}$ \\
\hline 6 & 16 & ArCMSdA6A67 & Euryarchaeota & Thermoplasmata & Thermoplasmatales & $\begin{array}{l}\text { Thermogymnomonas acidicola JCM } \\
13583(92 \%)\end{array}$ \\
\hline 7 & 3 & ArCoSdN9H63 & Euryarchaeota & Thermoplasmata & Thermoplasmatales & $\begin{array}{l}\text { Thermogymnomonas acidicola JCM } \\
13583(93 \%)\end{array}$ \\
\hline 8 & 24 & ArCMSdJ9B78 & Euryarchaeota & - & - & Clone hfmA029 (86 \%) \\
\hline 9 & 4 & ArCMSdA6A30 & Euryarchaeota & Thermoplasmata & Thermoplasmatales & $\begin{array}{l}\text { Thermogymnomonas acidicola JCM } \\
13583(88 \%)\end{array}$ \\
\hline 10 & 3 & ArCoSdN9D80 & Euryarchaeota & Thermoplasmata & Thermoplasmatales & $\begin{array}{l}\text { Thermogymnomonas acidicola JCM } \\
13583(94 \%)\end{array}$ \\
\hline 11 & 7 & ArCMSdO8B50 & Euryarchaeota & Thermoplasmata & Thermoplasmatales & $\begin{array}{l}\text { Thermogymnomonas acidicola JCM } \\
13583(94 \%)\end{array}$ \\
\hline 12 & 4 & ArCMSdO8B53 & Euryarchaeota & Thermoplasmata & Thermoplasmatales & $\begin{array}{l}\text { Thermogymnomonas acidicola JCM } \\
13583(90 \%)\end{array}$ \\
\hline 13 & 1 & ArCMSdA6A52 & Euryarchaeota & Thermoplasmata & Thermoplasmatales & Thermoplasma volcanium (84 \%) \\
\hline 14 & 2 & ArCMSdA6A84 & Euryarchaeota & Thermoplasmata & Thermoplasmatales & $\begin{array}{l}\text { Thermogymnomonas acidicola JCM } \\
13583(90 \%)\end{array}$ \\
\hline 15 & 3 & ArCoSdN9H35 & Euryarchaeota & Thermoplasmata & - & $\begin{array}{l}\text { Methanomassiliicoccus luminyensis } \\
\text { B10 }(80 \%)\end{array}$ \\
\hline 16 & 1 & ArCMSdA6A92 & Euryarchaeota & Thermoplasmata & Thermoplasmatales & $\begin{array}{l}\text { Thermogymnomonas acidicola JCM } \\
13583(91 \%)\end{array}$ \\
\hline 17 & 4 & ArCoSdN9H43 & Euryarchaeota & Thermoplasmata & Thermoplasmatales & $\begin{array}{l}\text { Thermogymnomonas acidicola JCM } \\
13583(88 \%)\end{array}$ \\
\hline 18 & 5 & ArCMSdO8A3 & Euryarchaeota & Thermoplasmata & - & $\begin{array}{l}\text { Methanomassiliicoccus luminyensis } \\
\text { B10 }(82 \%)\end{array}$ \\
\hline 19 & 1 & ArCMSdO8A13 & Euryarchaeota & Thermoplasmata & Thermoplasmatales & $\begin{array}{l}\text { Thermogymnomonas acidicola JCM } \\
13583(89 \%)\end{array}$ \\
\hline 20 & 1 & ArCMSdO8A16 & Euryarchaeota & Thermoplasmata & Thermoplasmatales & $\begin{array}{l}\text { Thermogymnomonas acidicola JCM } \\
13583(87 \%)\end{array}$ \\
\hline 21 & 2 & ArCoSdN9H67 & Euryarchaeota & Thermoplasmata & - & $\begin{array}{l}\text { Methanomassiliicoccus luminyensis } \\
\text { B10 }(83 \%)\end{array}$ \\
\hline 22 & 1 & ArCMSdO8A24 & Euryarchaeota & Thermoplasmata & Thermoplasmatales & $\begin{array}{l}\text { Thermogymnomonas acidicola JCM } \\
13583(88 \%)\end{array}$ \\
\hline 23 & 2 & ArCMSdO8A56 & Euryarchaeota & Thermoplasmata & Thermoplasmatales & $\begin{array}{l}\text { Thermogymnomonas acidicola JCM } \\
13583(89 \%)\end{array}$ \\
\hline 24 & 4 & ArCMSdO8A49 & Euryarchaeota & Thermoplasmata & Thermoplasmatales & $\begin{array}{l}\text { Thermoplasma volcanium GSS1 } \\
\text { (89\%) }\end{array}$ \\
\hline 25 & 1 & ArCMSdO8A54 & Euryarchaeota & Thermoplasmata & Thermoplasmatales & $\begin{array}{l}\text { Thermogymnomonas acidicola JCM } \\
13583(90 \%)\end{array}$ \\
\hline 26 & 3 & ArCMSdO8A74 & Euryarchaeota & Thermoplasmata & Thermoplasmatales & $\begin{array}{l}\text { Thermogymnomonas acidicola JCM } \\
13583(99 \%)\end{array}$ \\
\hline 27 & 1 & ArCMSdO8A85 & Euryarchaeota & Thermoplasmata & Thermoplasmatales & $\begin{array}{l}\text { Thermogymnomonas acidicola JCM } \\
13583(93 \%)\end{array}$ \\
\hline
\end{tabular}


Table 4 continued

\begin{tabular}{|c|c|c|c|c|c|c|}
\hline \multirow{2}{*}{$\begin{array}{l}\text { OTU } \\
\text { ID }\end{array}$} & \multirow{2}{*}{$\begin{array}{l}\text { Number of } \\
\text { sequences }\end{array}$} & \multirow{2}{*}{$\begin{array}{l}\text { Representative } \\
\text { sequence }\end{array}$} & \multicolumn{3}{|c|}{ Taxonomic affiliation } & \multirow[t]{2}{*}{ Closest relative ( $\%$ of identity) } \\
\hline & & & Phylum & Class & Order & \\
\hline 28 & 1 & ArCMSdO8A89 & Euryarchaeota & Thermoplasmata & - & $\begin{array}{l}\text { Methanomassiliicoccus luminyensis } \\
\text { B10 }(85 \%)\end{array}$ \\
\hline 29 & 5 & ArCMSdJ9A29 & - & - & - & $\begin{array}{l}\text { Candidatus Nitrosocaldus } \\
\text { yellowstonii HL72 (84 \%) }\end{array}$ \\
\hline 30 & 2 & ArCMSdO8C25 & - & - & - & $\begin{array}{l}\text { Candidatus Nitrososphaera } \\
\text { gargensis }(83 \%)\end{array}$ \\
\hline 31 & 1 & ArCMSdO8E23 & Euryarchaeota & Thermoplasmata & Thermoplasmatales & $\begin{array}{l}\text { Thermogymnomonas acidicola JCM } \\
13583(92 \%)\end{array}$ \\
\hline 32 & 15 & ArCMSdJ9C75 & Euryarchaeota & - & - & Clone SVB_Fis_02_pl37c09 $(86 \%)$ \\
\hline 33 & 16 & ArCMSdJ9C68 & Euryarchaeota & - & - & Clone hfmA029 (85 \%) \\
\hline 34 & 1 & ArCMSdJ9C55 & Euryarchaeota & Methanomicrobia & Methanomicrobiales & Clone hfmA029 (84\%) \\
\hline 35 & 2 & ArCoSdN9A45 & Euryarchaeota & - & - & Clone hfmA029 (85 \%) \\
\hline 36 & 15 & ArCoSdN9B9 & Thaumarchaeota & No class & Nitrososphaerales & $\begin{array}{l}\text { Candidatus Nitrososphaera sp. } \\
\text { EN76 }(96 \%)\end{array}$ \\
\hline 37 & 6 & ArCoSdN9F14 & Thaumarchaeota & No class & Cenarchaeales & $\begin{array}{l}\text { Candidatus Nitrosopumilus sp. } \\
\text { NM25 }(93 \%)\end{array}$ \\
\hline 38 & 11 & ArCoSdN9D53 & Euryarchaeota & - & - & Clone TG_FD0.2_SA043 (100\%) \\
\hline 39 & 2 & ArCoSdN9H79 & Euryarchaeota & Thermoplasmata & Thermoplasmatales & $\begin{array}{l}\text { Thermogymnomonas acidicola JCM } \\
13583(90 \%)\end{array}$ \\
\hline 40 & 1 & ArCoSdN9E14 & Euryarchaeota & Thermoplasmata & Thermoplasmatales & $\begin{array}{l}\text { Thermogymnomonas acidicola JCM } \\
13583(88 \%)\end{array}$ \\
\hline 41 & 1 & ArCoSdN9G7 & Euryarchaeota & Thermoplasmata & Thermoplasmatales & $\begin{array}{l}\text { Thermogymnomonas acidicola JCM } \\
13583(93 \%)\end{array}$ \\
\hline 42 & 1 & ArCoSdN9H80 & Euryarchaeota & Thermoplasmata & Thermoplasmatales & $\begin{array}{l}\text { Thermogymnomonas acidicola JCM } \\
13583(92 \%)\end{array}$ \\
\hline
\end{tabular}

OTU definition and taxonomic identification of representative sequences were done using mothur (Schloss et al. 2009; see "Materials and methods" for details). Only taxonomic affiliations with $100 \%$ similarity are shown. The closest relative was obtained by BLAST search on NCBI nr database

in a single OTU (OTU 29) belonged to an unknown group of Thaumarchaeota previously found in October 2008 and were affiliated with clone GBX-A-COQ1-158 isolated from an acidic hot spring (Fig. 3).

An increase in archaeal diversity was observed in the November 2009 library, with 25 OTUs belonging to the Euryarchaeota (69 clones corresponding to $61 \%$ of the sample) and to the Thaumarchaeota (22 clones corresponding to $19 \%$ of the sample, Fig. 3). The sequences from the Euryarchaeota were distributed in 22 OTUs. Fifteen were related to the order Thermoplasmatales, 11 of which (OTUs 1, 2, 4, 6, 7, 9, 10, 11, 17, 24, 26) were previously found in the April 2006 and October 2008 libraries (Fig. 3). As in the results observed in these two sampling periods, OTU 1 was also the most abundant group in the sample in November 2009 (32\%). Additionally, OTUs 15 and 21, also found in the two first libraries, were assigned to the order Methanomicrobia. The remaining five OTUs $(8,32,33,35$, and 38$)$, were not shown to be related to any known species and formed unknown groups of the Euryarchaeota (Fig. 3). Among these, the most abundant sequences belonging to OTU 38, displayed a strong similarity (99\%) with an uncultured archaeon clone LC15_L00B08 isolated from the monimolimnion of a stratified lake (Gregersen et al. 2009). The four other OTUs $(8,32,33$, and 35) were affiliated with the uncultured archaeon clones hfmA029 mainly present in the January 2009 library. The Thaumarchaeota detected in this study fell into different lineages clustered in three OTUs. The first (OTU 36) belonged to Thaumarchaeota group I.1b and the 15 sequences within this OTU showed from 95 to $96 \%$ similarity with Candidatus Nitrososphaera viennensis a chemolithoautotrophic ammonia-oxidizing archaeon (Tourna et al. 2011). The second (OTU 37) was assigned to Thaumarchaeota group I.1a and the sequences displayed $92-93 \%$ similarity with Candidatus Nitrosopumilus sp., another ammonia-oxidizing prokaryote (Matsutani et al. 2011). The last OTU (OTU 29), previously found in October 2008 could not be related to any known species. 


\section{Discussion}

Archaeal 16S rRNA gene analysis of the sediment sampled at the Reigous Creek showed that the Carnoulès archaeal community includes the phylum Euryarchaeota and Thaumarchaeota. The relatively low archaeal diversity revealed by molecular-based methods is consistent with the results of studies in similar environments (Bond et al. 2000; Baker and Banfield 2003; Bruneel et al. 2008; SánchezAndrea et al. 2011). This may reflect the limited number of different electron donors and acceptors available in this AMD and the high concentration of toxic compounds along with the low $\mathrm{pH}$. Most of the phylotypes identified in this study were related to genera and species usually found in extreme environments (hot springs, acidic springs, hydrothermal vents, etc.) and showed similarities with sequences obtained in previous studies of Tinto River and other AMD (Sánchez-Andrea et al. 2011; García-Moyano et al. 2007; Rowe et al. 2007, Fig. 3).

Regarding the dynamics of the archaeal community, our study showed that significant modifications in this community occurred throughout the sampling period. All the sampling periods showed differences in community structure and membership although April 2006 and October 2008 were more similar in terms of community structure. Similarity coefficient analysis showed that January 2009 was very different from all the other sampling periods. In January 2009, the archaeal community changed and diversity decreased. Almost all the sequences were related to an uncultured archaeon clone hfmA029 affiliated with methanogenic lineage (Methanothermobacter thermautotrophicus). This clone, hfmA029, previously found in April 2006 (OTU 8) in only $2 \%$ of the sample became the dominant population in January 2009. The differences in the archaeal community observed in January 2009 may result from a modification in the composition of the sediment, although the physicochemical analysis of the sediments appeared to be similar throughout the sampling period, and consisted mainly of an amorphous Fe(III)As $(\mathrm{V})$ hydroxysulfate mineral. Indeed, XRD analyses revealed that pyrite first appeared in October 2008. Likewise, since late 2007, a leakage of fine grey sulfide-reach sands out of the tailings pile has been observed after the rainfall events that generally occur in September and October. This is probably due to the corrosion of the drains at the bottom of the tailing stock that are responsible for the water discharge inside the mine tailing. In January 2009, the sulfide sands, originated from the tailings stock, formed a very thick layer (around $3 \mathrm{~cm}$ deep) in the bottom of the creek which could explain the change in the archaeal community.

In the Reigous sediment, most of the sequences were phylogenetically related to the order Thermoplasmatales, although none of the clones could be identified with high similarity $(>97 \%)$ as belonging to any cultured species. This order is represented by thermoacidophilic organisms (Reysenbach 2001), which often derive energy from sulfur oxidation or reduction. So far, the order contains three families, each represented by one genus: the Thermoplasmataecae, the Picrophilaceae and the Ferroplasmaceae (Itoh et al. 2007). The Thermoplasmataecae comprises species like Tp. acidophilum that couple the oxidation of organic carbon with reduction of elemental sulfur, whereas members of the Ferroplasmaceae are strict iron-oxidizing chemolithotrophs such as Ferroplasma acidiphilum (Itoh et al. 2007). Microorganisms affiliated with methanogenic Archaea such as Methanomassiliicoccus luminyensis were also identified. Methanogenic communities play an important role in the global carbon cycle, completing the conversion of organic carbon into methane gas by utilizing the metabolic products of bacteria $\left(\mathrm{CO}_{2}, \mathrm{H}_{2}\right.$, acetate, and formate) and other simple methyl compounds available in the environment (Sanz et al. 2011). Lastly, we found microorganisms involved in ammonia oxidation, a key step in the nitrogen cycle (Brochier-Armanet et al. 2011), with presence of sequences affiliated to Candidatus Nitrososphaera viennensis and Candidatus Nitrosopumilus sp. Until recently, ammonia oxidation, the first nitrification step of the nitrogen cycle was thought to be carried out only by autotrophic ammonia-oxidizing bacteria (AOB) belonging to the Beta- and Gammaproteobacteria lineages (Purkhold et al. 2000) occasionally supported by heterotrophic nitrifiers in soil environments (De Boer and Kowalchuk 2001). Ammonia-oxidizing Archaea (AOA) are members of the proposed novel Phylum Thaumarchaeota, and are currently being indentified in almost all environments (Brochier-Armanet et al. 2008). These Archaea may thus play a major role in the nitrogen cycle in the Carnoulès sediments.

Previous studies focused on the bacterial communities inhabiting the Carnoulès AMD sediment. These studies showed that the active population of bacteria also contained iron reducers, sulfate-reducing, and sulfur compound oxidizers, and both autotrophic and heterotrophic bacteria (Bruneel et al. 2011). Statistical analysis of genomic and proteomic data demonstrated that both metabolic specificity and partnerships can co-exist in this arsenic-rich sediment (Bertin et al. 2011). These processes include the fixation of inorganic carbon and nitrogen by several strains, in particular those belonging to the Thiomonas, Acidithiobacillus, and Gallionella related genera. However, this study did not find evidence for the presence of archaeal species among the dominant organisms, suggesting that they may represent a small proportion of the microbial community in the sediment. Despite the fact that we cannot really infer the implication of the Archaea 
detected in most of these metabolic pathways because most of them could not be affiliated to cultured species, we can point to their probable implication in a specific metabolism currently unknown in bacteria (Forterre et al. 2002), methanogenesis. Archaea are also involved in the nitrogen cycle (Candidatus Nitrososphaera viennensis and Candidatus Nitrosopumilus sp.) and some of them may also be involved in the sulfur and iron cycles (Thermoplasmatales). All these microorganisms may contribute to the remediation process observed in situ and could also be involved in the stability of this sediment by changing the ratio between oxidized and reduced forms of iron, arsenic, and sulfur compounds, promoting the formation and/or dissolution of the $\mathrm{Fe}(\mathrm{III})-\mathrm{As}(\mathrm{V})$ hydroxysulfate precipitates.

Because isolation and phenotypic characterization of many environmental Archaea are currently not possible, the physiological features and ecological significance of some Archaea detected in this AMD remain difficult to assess. Moreover, the fact that most of the archaeal sequences were only distantly related $(<94 \%$ similarity) to known archaeal species suggests that other taxa may exist. Additionally, the contradictions observed in the taxonomic affiliation resulting from the $16 \mathrm{~S}$ rRNA phylogenetic reconstruction (Fig. 3) and the Greengenes classification (Table 4) suggest that there is still a lack of information making the taxonomic identification difficult to assess. Indeed, almost half of the 16S rRNA gene sequences archived in GenBank database lacks clear taxonomic information (DeSantis et al. 2006). As a consequence, different authors use different names for uncultured clusters which lead to conflicting nomenclatures. Recently developed high-throughput techniques (metagenomics, metaproteomics, and microarrays) may help link the identity of AMD-promoting prokaryotes to their function in mining environments (Mohapatra et al. 2011; Bertin et al. 2011) in the absence of laboratory culture. In the future, these new genomic tools should provide a more precise assessment of the archaeal diversity that will probably lead to substantial changes in current archaeal phylogeny and taxonomy (Brochier-Armanet et al. 2008; Schleper et al. 2005) and to a better understanding of the evolution and metabolic capacities of uncultured Archaea. In conclusion, to increase our insight into the functioning of these highly acidic environments and to elucidate the role of these microorganisms, both improving culture strategies for further physiological and metabolic characterization of newly detected species and a greater sequencing effort are still needed.

Acknowledgments The French CRG is gratefully acknowledged for provision of beamtime on the FAME BM30B beamline. This work was supported by EC2CO CNRS/INSU program, by ACI/FNS Grant
\#3033 and by SESAME IdF Grant \#1775. Part of the field chemical data was acquired through the OSU OREME.

\section{References}

Altschul SF, Gish W, Miller W, Myers EW, Lipman DJ (1990) Basic local alignment search tool. J Mol Biol 215(3):403-410

Anisimova M, Gascuel O (2006) Approximate likelihood-ratio test for branches: a fast, accurate, and powerful alternative. Syst Biol 55(4):539-552

Ashelford KE, Chuzhanova NA, Fry JC, Jones AJ, Weightman AJ (2006) New screening software shows that most recent large 16S rRNA gene clone libraries contain chimeras. Appl Environ Microbiol 72(9):5734-5741

Baker BJ, Banfield JF (2003) Microbial communities in acid mine drainage. FEMS Microbiol Ecol 44(2):139-152

Bertin PN, Heinrich-Salmeron A, Pelletier E, Goulhen-Chollet F, Arsène-Ploetze F, Gallien S, Lauga B, Casiot C, Calteau A, Vallenet D, Bonnefoy V, Bruneel O, Chane-Woon-Ming B, Cleiss-Arnold J, Duran R, Elbaz-Poulichet F, Fonknechten N, Giloteaux L, Halter D, Koechler S, Marchal M, Mornico D, Schaeffer C, Smith AAT, Van Dorsselaer A, Weissenbach J, Medigue C, Le Paslier D (2011) Metabolic diversity among main microorganisms inside an arsenic-rich ecosystem revealed by meta- and proteo-genomics. ISME J 5(11):1735-1747

Bond PL, Smriga SP, Banfield JF (2000) Phylogeny of microorganisms populating a thick, subaerial, predominantly lithotrophic biofilm at an extreme acid mine drainage site. Appl Environ Microbiol 66(9):3842-3849

Bowell RJ (1994) Sorption of arsenic by iron oxides and oxyhydroxides in soils. Appl Geochem 9(3):279-286

Brochier-Armanet C, Boussau B, Gribaldo S, Forterre P (2008) Mesophilic crenarchaeota: proposal for a third archaeal phylum, the Thaumarchaeota. Nat Rev Microbiol 6(3):245-252

Brochier-Armanet C, Forterre P, Gribaldo S (2011) Phylogeny and evolution of the Archaea: one hundred genomes later. Curr Opin Microbiol 14(3):274-281

Brofft JE, McArthur JV, Shimkets LJ (2002) Recovery of novel bacterial diversity from a forested wetland impacted by reject coal. Environ Microbiol 4(11):764-769

Bruneel O, Personne JC, Casiot C, Leblanc M, Elbaz-Poulichet F, Mahler BJ, Le Fleche A, Grimont PA (2003) Mediation of arsenic oxidation by Thiomonas sp. in acid-mine drainage (Carnoules, France). J Appl Microbiol 95(3):492-499

Bruneel O, Pascault N, Egal M, Bancon-Montigny C, Goñi-Urriza M, Elbaz-Poulichet F, Personné JC, Duran R (2008) Archaeal diversity in a $\mathrm{Fe}-\mathrm{As}$ rich acid mine drainage at Carnoulès (France). Extremophiles 12(4):563-571

Bruneel O, Volant A, Gallien S, Chaumande B, Casiot C, Carapito C, Bardil A, Morin G, Brown GE, Personné JC, Le Paslier D, Schaeffer C, Van Dorsselaer A, Bertin PN, Elbaz-Poulichet F, Arsene-Ploetze F (2011) Characterization of the active bacterial community involved in natural attenuation processes in arsenicrich creek sediments. Microb Ecol 61(4):793-810

Casiot C, Morin G, Juillot F, Bruneel O, Personné JC, Leblanc M, Duquesne K, Bonnefoy V, Elbaz-Poulichet F (2003) Bacterial immobilization and oxidation of arsenic in acid mine drainage (Carnoulès creek, France). Water Res 37(12):2929-2936

De Boer W, Kowalchuk GA (2001) Nitrification in acid soils: microorganisms and mechanisms. Soil Biol Biochem 33(7-8):853-866

DeLong EF (1992) Archaea in coastal marine environments. Proc Natl Acad Sci USA 89(12):5685-5689 
DeSantis TZ, Hugenholtz P, Larsen N, Rojas M, Brodie EL, Keller K, Huber T, Dalevi D, Hu P, Andersen GL (2006) Greengenes, a chimera-checked 16S rRNA gene database and workbench compatible with ARB. Appl Environ Microbiol 72(7):50695072

Dopson M, Baker-Austin C, Hind A, Bowman JP, Bond PL (2004) Characterization of Ferroplasma isolates and Ferroplasma acidarmanus sp. nov., extreme acidophiles from acid mine drainage and industrial bioleaching environments. Appl Environ Microbiol 70(4):2079-2088

Dridi B, Fardeau ML, Ollivier B, Raoult D, Drancourt M (2011) The antimicrobial resistance pattern of cultured human methanogens reflects the unique phylogenetic position of archaea. J Antimicrob Chemother 66(9):2038-2044

Edwards KJ, Goebel BM, Rodgers TM, Schrenk MO, Gihring TM, Cardona MM, Hu B, McGuire MM, Hamers RJ, Pace NR, Banfield JF (1999) Geomicrobiology of pyrite $\left(\mathrm{FeS}_{2}\right)$ dissolution: Case study at Iron Mountain, California. Geomicrobiol J 16(2):155-179

Edwards KJ, Bond PL, Gihring TM, Banfield JF (2000) An archaeal iron-oxidizing extreme acidophile important in acid mine drainage. Science 287(5459):1796-1799

Egal M, Casiot C, Morin G, Elbaz-Poulichet F, Cordier MA, Bruneel O (2010) An updated insight into the natural attenuation of As concentrations in Reigous Creek (southern France). Appl Geochem 25(12):1949-1957

Forterre P, Brochier C, Philippe H (2002) Evolution of the Archaea. Theor Popul Biol 61(4):409-422

García-Moyano A, González-Toril E, Aguilera A, Amils R (2007) Prokaryotic community composition and ecology of floating macroscopic filaments from an extreme acidic environment, Río Tinto (SW, Spain). Syst Appl Microbiol 30(8):601-614

Golyshina OV, Pivovarova TA, Karavaiko GI, Kondrateva TF, Moore ER, Abraham WR, Lunsdorf H, Timmis KN, Yakimov MM, Golyshin PN (2000) Ferroplasma acidiphilum gen. nov., sp. nov., an acidophilic, autotrophic, ferrous-iron-oxidizing, cellwall-lacking, mesophilic member of the Ferroplasmaceae fam. nov., comprising a distinct lineage of the Archaea. Int J Syst Evol Microbiol 50 Pt 3:997-1006

Good IJ (1953) The population frequencies of species and the estimation of population parameters. Biometrika 40(3/4):237264

Gregersen LH, Habicht KS, Peduzzi S, Tonolla M, Canfield DE, Miller M, Cox RP, Frigaard NU (2009) Dominance of a clonal green sulfur bacterial population in a stratified lake. FEMS Microbiol Ecol 70(1):30-41

Guindon S, Gascuel O (2003) A simple, fast, and accurate algorithm to estimate large phylogenies by maximum likelihood. Syst Biol 52(5):696-704

Hallberg KB (2010) New perspectives in acid mine drainage microbiology. Hydrometallurgy 104(3-4):448-453

Hohmann C, Morin G, Ona-Nguema G, Guigner JM, Brown GE Jr, Kappler A (2011) Molecular-level modes of As binding to $\mathrm{Fe}$ (III) (oxyhydr)oxides precipitated by the anaerobic nitratereducing $\mathrm{Fe}(\mathrm{II})$-oxidizing Acidovorax sp. strain BoFeN1. Geochim Cosmochim Acta 75(17):4699-4712

Huber R, Sacher M, Vollmann A, Huber H, Rose D (2000) Respiration of arsenate and selenate by hyperthermophilic archaea. Syst Appl Microbiol 23(3):305-314

Itoh T, Yoshikawa N, Takashina T (2007) Thermogymnomonas acidicola gen. nov., sp. nov., a novel thermoacidophilic, cell wall-less archaeon in the order Thermoplasmatales, isolated from a solfataric soil in Hakone, Japan. Int J Syst Evol Microbiol 57(11):2557-2561

Johnson DB, Hallberg KB (2003) The microbiology of acidic mine waters. Res Microbiol 154(7):466-473
Maillot F (2011) Structure locale des nano-oxyhydroxydes de fer(III) de type ferrihydrite et schwertmannite. PhD thesis, UPMC, Paris

Matsutani N, Nakagawa T, Nakamura K, Takahashi R, Yoshihara K, Tokuyama T (2011) Enrichment of a novel marine ammoniaoxidizing archaeon obtained from sand of an eelgrass zone. Microbes Environ 26(1):23-29

Mohapatra BR, Douglas Gould W, Dinardo O, Koren DW (2011) Tracking the prokaryotic diversity in acid mine drainagecontaminated environments: a review of molecular methods. Miner Eng 24(8):709-718

Morin G, Juillot F, Casiot C, Bruneel O, Personne JC, ElbazPoulichet F, Leblanc M, Ildefonse P, Calas G (2003) Bacterial formation of tooeleite and mixed arsenic(III) or arsenic(V)iron(III) gels in the Carnoules acid mine drainage, France. A XANES, XRD, and SEM study. Environ Sci Technol 37(9):1705-1712

Ona-Nguema G, Morin G, Juillot F, Calas G, Brown GE Jr (2005) EXAFS analysis of arsenite adsorption onto two-line ferrihydrite, hematite, goethite, and lepidocrocite. Environ Sci Technol 39(23):9147-9155

Oremland RS, Stolz JF (2003) The ecology of arsenic. Science 300(5621):939-944

Purkhold U, Pommerening-Roser A, Juretschko S, Schmid MC, Koops HP, Wagner M (2000) Phylogeny of all recognized species of ammonia oxidizers based on comparative 16S rRNA and amoA sequence analysis: implications for molecular diversity surveys. Appl Environ Microbiol 66(12):5368-5382

Reysenbach AL (2001) Order I. Thermoplasmatales ord. nov. In: Boone DR, Castenholz RW, Garrity GM (eds) Bergey's manual of systematic bacteriology, vol 1, 2nd edn. Springer, New York, p 335

Rodier J, Broutin JP, Chambon P, Champsaur H, Rodi L (1996) L'Analyse des Eaux. Dunod, Paris, p 1383

Rowe OF, Sánchez España J, Hallberg KB, Johnson DB (2007) Microbial communities and geochemical dynamics in an extremely acidic, metal-rich stream at an abandoned sulfide mine (Huelva, Spain) underpinned by two functional primary production systems. Environ Microbiol 9(7):1761-1771

Saitou N, Nei M (1987) The neighbor-joining method: a new method for reconstructing phylogenetic trees. Mol Biol Evol 4(4): $406-425$

Samanta G, Clifford DA (2005) Preservation of inorganic arsenic species in groundwater. Environ Sci Technol 39(22):8877-8882

Sánchez España J, Pamo EL, Pastor ES, Andrés JR, Rubí JAM (2005) The natural attenuation of two acidic effluents in Tharsis and La Zarza-Perrunal mines (Iberian Pyrite Belt, Huelva, Spain). Environ Geol 49(2):253-266

Sánchez-Andrea I, Rodriguez N, Amils R, Sanz JL (2011) Microbial diversity in anaerobic sediments at Rio Tinto, a naturally acidic environment with a high heavy metal content. Appl Environ Microbiol 77(17):6085-6093

Sanz JL, Rodriguez N, Diaz EE, Amils R (2011) Methanogenesis in the sediments of Rio Tinto, an extreme acidic river. Environ Microbiol 13(8):2336-2341

Schleper C, Jurgens G, Jonuscheit M (2005) Genomic studies of uncultivated archaea. Nat Rev Microbiol 3(6):479-488

Schloss PD, Westcott SL, Ryabin T, Hall JR, Hartmann M, Hollister EB, Lesniewski RA, Oakley BB, Parks DH, Robinson CJ, Sahl JW, Stres B, Thallinger GG, Van Horn DJ, Weber CF (2009) Introducing mothur: open-Source, platform-independent, community-supported software for describing and comparing microbial communities. Appl Environ Microbiol 75(23):7537-7541

Singleton DR, Furlong MA, Rathbun SL, Whitman WB (2001) Quantitative comparisons of 16S rRNA gene sequence libraries from environmental samples. Appl Environ Microbiol 67(9): 4374-4376 
Thompson JD, Plewniak F, Thierry J, Poch O (2000) DbClustal: rapid and reliable global multiple alignments of protein sequences detected by database searches. Nucleic Acids Res 28(15):2919-2926

Tourna M, Stieglmeier M, Spang A, Könneke M, Schintlmeister A, Urich T, Engel M, Schloter M, Wagner M, Richter A, Schleper C (2011) Nitrososphaera viennensis, an ammonia oxidizing archaeon from soil. Proc Natl Acad Sci USA 108(20):8420-8425
Yue JC, Clayton MK (2005) A similarity measure based on species proportions. Commun Stat Theory Methods 34(11):2123-2131

Zeikus JG, Wolee RS (1972) Methanobacterium thermoautotrophicus sp. n., an anaerobic, autotrophic, extreme thermophile. J Bacteriol 109(2):707-713 